\begin{tabular}{|c|c|}
\hline Dostępne online www.journals.wco.pl/los & Letters in Dncology Science \\
\hline Zeszyty Naukowe WCO, Letters in Oncology Science 2 & ISSN 2543-6724 \\
\hline Praca poglądowa/Review paper & \\
\hline
\end{tabular}

\title{
Nowe technologie wykorzystywane w procesie teleradioterapii w świetle doniesień zaprezentowanych podczas konferencji ASTRO 57 w San Antonio
}

\section{New technology in teleradiotherapy presented at the ASTRO 57 conference in San Antonio}

\author{
Małgorzata Skórska ${ }^{1}$ \\ ${ }^{1}$ Zakład Fizyki Medycznej, Wielkopolskie Centrum Onkologii, Poznań, Polska
}

\section{Streszczenie}

Celem niniejszej pracy było zwrócenie uwagi na najnowsze osiągnięcia technologiczne i trendy w teleradioterapii. Analizę oparto o wybrane raporty oraz problemy badawcze zaprezentowane podczas dorocznego spotkania ASTRO 57 w San Antonio.

\begin{abstract}
The aim of this paper was to highlight the newest technological advances and trends related to teleradiotherapy. The analysis was based on selected reports and some research problems presented during ASTRO 57th Annual Meeting in San Antonio.

Stowa kluczowe: radioterapia; nowoczesna technologia; drukarki 3D; radioterapia sterowana obrazem; MR-akcelerator liniowy

Keywords: radiotherapy; new technology; 3D printers; Image Guided Radiation Therapy; MR-linac

\section{Wprowadzenie}

„Technology meets patient care”, czyli “Technologia w służbie pacjentowi” to temat przewodni konferencji organizowanej w San Antonio w dniach 18-21.10.2015 przez American Society for Radiation Oncology ASTRO. Niewątpliwie nowoczesne technologie zrewolucjonizowały radioterapię (RT ang. radiation therapy) na świecie. Mimo to nadal poszukiwane są coraz lepsze rozwiązania w dziedzinie inżynierii medycznej oraz technik komputerowych. Z tego też powodu, na każdej sesji ASTRO 57 związanej z fizyką medyczną można było zapoznać się z badaniami, które prawdopodobnie w ciągu kilku lat przyczynią się do znacznej poprawy leczenia pacjentów onkologicznych.
\end{abstract}

Adres do korespondencji

Małgorzata Skórska,

Zakład Fizyki Medycznej,

Wielkopolskie Centrum Onkologii, ul. Garbary 15, 61-866 Poznań, Polska

e-mail: malgorzata.skorska@wco.pl 


\section{Najistotniejsze wyniki}

Zaawansowanetechnologiezaimplementowanezostałym.in.wbadaniach nad połączeniem magnetycznego rezonansu jądrowego (MR ang. magnetic resonance) z liniowym akceleratorem lub aparatem zawierającym źródła kobaltu-6o (Co6o). Takie hybrydy zapewniają wiele zalet:

- wysoki kontrast tkanek miękkich

- brak ekspozycji pacjenta na promieniowanie X podczas obrazowania

- trójwymiarowy obraz

- możliwość obrazowania zarówno anatomii jak i fizjologii

- brak konieczności wszczepiania znaczników w celu pozycjonowania pacjenta na aparacie terapeutycznym

Pierwsze komercyjne urządzenie tego typu jest już używane klinicznie [1]. Składa się ono z trzech źródeł Co6o (służących do terapii promieniowaniem jonizującym) oraz dwóch części magnesu nadprzewodzącego (służących do obrazowania). Zespoły badawcze z Australii [2] oraz Stanów Zjednoczonych [3] również zaproponowały urządzenie łączące MR ze źródłami Co-6o. Natomiast grupy z Holandii [4] oraz Kanady [5] opracowują metodę połączenia przyspieszacza liniowego z MR. Wiele z tych nowatorskich systemów wykorzystuje małe pole magnetyczne ok. $0.20-0.35 \mathrm{~T}$ w celu zmniejszenia geometrycznych zniekształceń oraz interferencji z systemem do radioterapii [6].

W związku z licznymi zaletami wyżej wymienionych hybryd MR-radioterapeutycznych (MR-RT) oraz coraz większą ich dostępnością wiele uwagi na konferencji ASTRO 57 poświęcono organizacji procedur radioterapeutycznych tylko na bazie obrazów MR. Oznacza to wyeliminowanie tomografii komputerowej (TK), symulatorów terapeutycznych oraz urządzeń do radioterapii sterowanej obrazem (IGRT, ang. Image Guided Radiotherapy) i zastąpienia ich hybrydą MR-RT. Wówczas jedynie na bazie obrazów MR odbywać się będzie:

- konturowanie obszarów tarczowych i narządów krytycznych

- obliczanie rozkładu dawki w ciele pacjenta

- pozycjonowanie pacjenta na aparacie terapeutycznym

Jednakże system pracy w oparciu o MR-RT niesie ze sobą pewne ograniczenia. Są one głównie związane ze zniekształceniami przestrzennymi obrazu MR (co może negatywnie wpływać na konturowanie oraz pozycjonowanie) oraz brakiem prostej konwersji sygnału MR na gęstość elektronową, która niezbędna jest do prawidłowego obliczenia rozkładu dawki promieniowania jonizującego w ciele pacjenta.

W ciągu ostatnich dwóch dekad opracowano kilka metod otrzymania obrazów diagnostycznych zawierających współczynniki pochłaniania poszczególnych tkanek, które są porównywalne z danymi utworzonymi na podstawie TK. Takie obrazy diagnostyczne nazwano „syntetyczne TK” lub „pseudo TK”. Jedna z tych metod opiera się na atlasach anatomicznych. Polega ona na wykonaniu w krótkim odstępie czasowym obrazów TK i MR tego samego pacjenta. Następnie, porównuje się ze sobą te obrazy i na podstawie obrazów TK można stworzyć mapę gęstości elektronowej na MR. Po zebraniu odpowiedniej liczby takich danych dla różnych chorych można stworzyć bazę anatomiczną, dzięki której dla dowolnego obrazu MR będzie można wygenerować odpowiadającą mu mapę gęstości elektronowych. Szczegółowe dane dotyczące tej metody można znaleźć w pracy Dowling et al. [7] czy Hofmann et al. [8] Niewątpliwą jej zaletą jest konieczność wykonania tylko jednej sekwencji MR dla danego chorego. Jednak należy pamiętać, że narzędzie to będzie miało niską efektywność dla niestandardowych pacjentów np. z endoprotezą. Inna metoda otrzymywania syntetycznych TK jest oparta na klasyfikacji. Polega na wykonaniu wielu różnych sekwencji MR, dzięki którym istnieje możliwość wyodrębnienia poszczególnych grup tkanek (kości, powietrze, itp.), a następnie za pomocą matematycznych algorytmów określenie z pewnym prawdopodobieństwem do której grupy dany obszar należy. Metodę tą wykorzystał m.in. Korhonen et al. [9], Hu et al. [10], Rank et al [11] czy Kim et al. [12].

Podczas konferencji ASTRO 57 zaprezentowano również nowe możliwości wytwarzania bolusów oraz kompensatorów niezbędnych podczas pewnych technik radioterapii. Bolusy są używane w celu wyrównanie ewentualnych nierówności ciała pacjenta lub zwiększenia dawki promieniowania jonizującego na powierzchni skóry. Niestety proces wytwarzania indywidualnego bolusa jest często procesem żmudnym i pracochłonnym. Natomiast standardowe bolusy często nie spełniają oczekiwań. Nowe technologie w postaci drukarek 
przestrzennych (3D) znalazły zastosowanie w radioterapii procesie tworzenia indywidualnych bolusów i kompensatorów. Wiąże się to ze zmniejszeniem kosztów zakupu takiej drukarki oraz ich coraz większa popularność i przystępność. Jeden z prelegentów stwierdzil, iż wkrótce wytwarzanie tradycyjnych bolusów i kompensatorów (m.in. do protonoterapii) przestanie być opłacalne, gdyż koszty wydruku 3D będą znacznie mniejsze, natomiast jakość będzie porównywalna lub nawet lepsza.

Obecnie najpopularniejsze drukarki 3D pracują w technologii:

- osadzania topionego materiału (ang. fused deposition modeling; FDM)

- stereolitografii (ang. stereolithography; SLA)

Najnowsza technologia druku 3D nosi nazwę CLIP (ang. continuous liquid interface production). Jest ona 25 do 100 razy szybsza niż tradycyjne drukarki 3D.

Przykładowe zastosowanie drukarek przestrzennych w radioterapii opisano w pracach $\mathrm{Su}$ et al. [13] oraz Burleson et al. [14].

Zdecydowanie dużo uwagi na konferencji ASTRO 57 poświęcono również ograniczeniu dawki promieniowania jonizującego pochodzącej z obrazowania przed każdą frakcją radioterapeutyczną. Obecnie technika IGRT jest standardem w wielu ośrodkach. Wiąże się to oczywiście z faktem, iż anatomia pacjenta jest obrazowana każdego dnia przed lub w trakcie leczenia. Niestety procedura ta powoduje, iż w ciele chorego deponowana jest dodatkowa dawka promieniowania. Ponadto zwrócono szczególną uwagę na fakt, że nieumiejętne posługiwanie się nowymi technologiami może przyczynić się do niewłaściwej lub nadmiernej ekspozycji chorego. Prof. Katja Langen szczegółowo omówiła raport dotyczący zapewnienia bezpieczeństwa i jakości procedur IGRT [15]. Szczególną uwagę zwróciła na konieczność utworzenia w każdym ośrodku ,zespołu IGRT”, w skład którego wchodzi: fizyk medyczny, elektroradiolog oraz lekarz radioterapeuta. Zadaniem tej grupy jest stworzenie protokołów postępowania w trakcie procedur IGRT oraz zapewnienie, że marginesy dodawane do obszaru tarczowego podczas procesu planowania leczenia są adekwatne do jakości leczenia oferowanej w danym ośrodku. Ponadto powinna ona rozwiązywać wszelkie problemy interdyscyplinarne związane z IGRT. Należy tu podkreślić fakt, iż technika IGRT wiąże się również z wydłużeniem czasu leczenia przypadającego na jednego pacjenta oraz czasu potrzebnego na wykonanie niezbędnych testów kontroli jakości [16]. Prof. Langen zaznaczyła konieczność dodatkowych szkoleń wszystkich grup zawodowych zaangażowanych w proces IGRT.

Drugim bardzo ważnym aspektem poruszonym podczas tej sesji przez prof. George Ding było porównanie

\begin{tabular}{|c|c|}
\hline \multicolumn{2}{|c|}{ obrazowanie megavoltowe (MV) } \\
\hline 2D MV (EPID) & $3-5 \mathrm{cGy}$ \\
\hline MVCT (HT) & $1-3 \mathrm{cGy}$ \\
\hline MV-CBCT & $4-5 \mathrm{cGy}$ \\
\hline \multicolumn{2}{|c|}{ obrazowanie kilowoltowe $(\mathrm{kV})$} \\
\hline 2D kV & $0.1-1 \mathrm{cGy}$ \\
\hline kV CBCT: & \\
tkanka miękka & $0.1-3 \mathrm{cGy}$ \\
tkanka kostna & $0.3-6 \mathrm{cGy}$ \\
\hline
\end{tabular}

Tabela 1. Zestawienie średnich dawek pochłoniętych dla różnego rodzaju technik IGRT [18]. Dawka dla zdjęć 2D dotyczy zawsze pary ortogonalnych obrazów. EPID - ang. Electronic Portal Imaging Device; MVCT - ang. Megavoltage Computed Tomography; HT - ang. Helical Tomotherapy; CBCT - ang. Cone-Beam Computed Tomograpy.

dawki pochłoniętej podczas różnego typu obrazowania IGRT. Zwrócono uwagę na fakt, iż w dobie licznych narzędzi pomocnych w wizualizowaniu anatomii pacjenta, najbardziej rozpowszechnione są takie, które wykorzystują promieniowanie jonizujące. Obecnie można wykonywać obrazy planarne (2D) lub wolumetryczne (3D), z zastosowaniem wiązki o zakresie energetycznym kilo- (ang. kilovoltage; kV) lub megawoltowym (ang. megavoltage; MV). Zrozumienie zalet i wad wyżej wymienionych metod IGRT, 
pozwala dobrać odpowiednią procedurę dla każdego pacjenta[17], w celu zminimalizowania ekspozycji na promieniowanie jonizujące. Prof. Ding postanowił odpowiedzieć na pytanie, czy dawka pochłonięta przez pacjenta podczas obrazowania przed frakcją radioterapeutyczną jest na tyle duża, że należy się jej bać oraz co zrobić żeby ją zminimalizować? W tabeli 1 przedstawiono typowe dawki pochłonięte dla różnych technik obrazowania IGRT [18]. Spośród urządzeń wykorzystujących wiązkę MV najniższe dawki pochłonięte otrzymano dla Tomoterapii (HT - ang. Helical Tomotherapy). Wartości te są nawet mniejsze niż dla pary ortogonalnych zdjęć MV dzięki obniżeniu energii nominalnej wiązki fotonowej z $6 \mathrm{MeV}$ do 3,5 MeV [19]. Ponadto w HT zyskujemy możliwość weryfikacji ułożenia pacjenta zarówno po strukturach kostnych jak i tkankach miękkich. Należy zauważyć, że spośród wszystkich technik wymienionych w tabeli 1 , najniższa dawka zostanie zdeponowana podczas ortogonalnych kV zdjęć planarnych. Ponadto, warto przypomnieć iż wykonując obrazowanie $\mathrm{kV}$ mamy do czynienia głównie $\mathrm{z}$ efektem fotoelektrycznym, podczas którego w tkance kostnej często następuje całkowita absorpcja padającego fotonu promieniowania rentgenowskiego. Wiąże się to oczywiście ze zwiększeniem dawki pochłoniętej w kościach w stosunku do tkanek miękkich, co możemy zauważyć w tabeli 1 dla obrazowania 3D.

Następnie przedstawiono kilka metod mających na celu obniżenie dawki pochłoniętej pochodzącej z procedur IGRT. Ding et al. [20, 21] wykazał, że zaktualizowanie oprogramowania (OBI 1.3 vs. OBI 1.4, Varian Medical Systems, Palo Alto, CA) może spowodować nawet piętnastokrotne zmniejszenie dawki. Natomiast poprzez odpowiednie ukierunkowanie źródła promieniowania rentgenowskiego (np. od strony tylnej zamiast przedniej) podczas procedury IGRT można trzykrotnie zredukować dawkę dla soczewek. Kolejne propozycje [20-22] to zmniejszenie długości skanowania pacjenta, dobór odpowiednich parametrów ekspozycji oraz używanie filtru tzw. „bow-tie”. Należy również pamiętać o tym, że dawka pochłonięta może wzrosnąć nawet dwukrotnie gdy wielkość pacjenta zmaleje. Opis szczegółowego postępowania minimalizującego dawkę pochłoniętą podczas obrazowania w trakcie radioterapii będzie zawarty w raporcie „AAPM TG-180” pt. "Modeling and Accounting for the Imaging Guidance Radiation Doses to Radiotherapy Patients in Treatment Planning”, który powinien ukazać się w najbliższym czasie.

\section{Podsumowanie}

Podczas zeszłorocznego spotkania ASTRO 56 dużo uwagi poświęcono procedurom stereotaktycznym [23] oraz nowoczesnym metodom planowania leczenia [24]. Natomiast ASTRO 57 zdominowała tematyka związana z nowymi technologiami. Szczególną uwagę zwracano na korzyści jakie niesie ze sobą dane narzędzie radioterapeutyczne oraz konieczność świadomego posługiwania się nim, aby jego zalety wykorzystać jak najlepiej dla dobra pacjenta.

\section{Konflikt interesu / Conflict of interest}

Nie występuje. / None.

\section{Finansowanie / Financial support}

Artykuł został sfinansowany z grantu Wielkopolskiego Centrum Onkologii w Poznaniu, nr 18/2015(110); 6/07/2015/FIZ/WCO/16. / This work was supported by the Greater Poland Cancer Centre, grant no. 18/2015(110); 6/07/2015/FIZ/WCO/16.

\section{Etyka/Ethics}

Treści przedstawione w artykule są zgodne z zasadami Deklaracji Helsińskiej, dyrektywami EU oraz ujednoliconymi wymaganiami dla czasopism biomedycznych. 


\section{Piśmiennictwo}

[1] ViewRay ${ }^{\text {тм }}$ Announces World's First Patients Treated Using MRI-Guided Radiation Therapy PR Newswire2014. 2014, February 5 . URL: http://www.prnewswire.com/news-releases/viewrayannounces-worlds-first-patients-treated-using-mri-guided-radiation-therapy-243806571.html. Dostęp z dnia 19.01.2016.

[2] Kron T, Eyles D, John SL, Battista J . Magnetic resonance imaging for adaptive cobalt tomotherapy: A proposal . J Med Phys 2006;31:242-54 .

[3] Dempsey JF, Benoit D , Fitzsimmons JR, Haghighat A, Li JG, Low DA, et al . A Device for Realtime 3D Image-Guided IMRT. Int J Radiat Oncol Biol Phys 2005;63:S202 .

[4] Raaymakers BW, Lagendijk JJ, Overweg J, Kok JG, Raaijmakers AJ, Kerkhof EM, et al . Integrating a 1.5 T MRI scanner with a 6 MV accelerator: proof of concept . Phys Med Biol 2009;54:N229-37 .

[5] Fallone BG, Murray B, Rathee S, Stanescu T, Steciw S, Vidakovic S, et al . First MR images obtained during megavoltage photon irradiation from a prototype integrated linac-MR system. Med Phys 2009;36:2084-8

[6] Noel CE, Parikh PJ, Spencer CR, Green OL, Hu Y, Mutic S, et al. Comparison of onboard low-field magnetic resonance imaging versus onboard computed tomography for anatomy visualization in radiotherapy. Acta Oncol 2015;54(9):1474-82.

[7] Dowling JA, Lambert J, Parker J, Salvado O, Fripp J, Capp A, et al. An atlas-based electron density mapping method for magnetic resonance imaging (MRI)-alone treatment planning and adaptive MRIbased prostate radiation therapy. Int $J$ Radiat Oncol Biol Phys 2012;83:e5-11

[8] Hofmann M, Steinke F, Scheel V, Charpiat G, Farquhar J, Aschoff P, et al. MRI-based attenuation correction for PET/MRI: a novel approach combining pattern recognition and atlas registration. Journal of Nuclear Medicine 2008;49(11):1875-83

[9] Korhonen J, Kapanen M, Keyriläinen J, Seppälä T, Tenhunen M. A dual model HU conversion from MRI intensity values within and outside of bone segment for MRI-based radiotherapy treatment planning of prostate cancer. Med Phys 2014; 41(1):011704.

[10] Su KH, Hu L, Stehning C, Helle M, Qian P, Thompson CL, et al. Generation of brain pseudo-CTs using an undersampled, single-acquisition UTE-mDixon pulse sequence and unsupervised clustering. Med Phys 2015;42(8):4974-86.

[11] Rank CM, Tremmel C, Hünemohr N, Nagel AM, Jäkel O, Greilich S. MRI-based treatment plan simulation and adaptation for ion radiotherapy using a classification-based approach. Radiat Oncol 2013;8:51.

[12] Kim J, Glide-Hurst C, Doemer A, Wen N, Movsas B, Chetty IJ. Implementation of a novel algorithm for generating synthetic CT images from magnetic resonance imaging data sets for prostate cancer radiation therapy. Int J Radiat Oncol Biol Phys 2015;91(1):39-47.

[13] Su S, Moran K, Robar J. Design and production of 3D printed bolus for electron radiation therapy. J Appl Clin Med Phys 2014:15(4):194-211.

[14] Burleson S, Baker J, Hsia AT, Xu Z. Use of 3D printers to create a patient-specific 3D bolus for external beam therapy. J Appl Clin Med Phys 2015;16(3):5247

[15] Affray DA, Langen KM, Mageras G, Dawson LA, Yan D, Adams R, et al. Assuring Safety and Quality in Image Guided Delivery Of Radiation Therapy. ASTRO White Paper; Practical Radiation Oncology (2013)

[16] Kanakavelu N, Samuel EJ. Assessment and evaluation of MV image guidance system performance in radiotherapy. Rep Pract Oncol Radiother 2015;20(3):188-97.

[17] Martins L, Couto JG, Barbosa B. Use of planar kV vs. CBCT in evaluation of setup errors in oesophagus carcinoma radiotherapy. Rep Pract Oncol Radiother 2016;21(1):57-62.

[18] Ding G, Patient dose and dose raduction techniques for kV and MV IGRT, Materiały zjazdowe konferencji ASTRO 57, San Antonio, 18-21.10.2015.

[19] Mackie TR, Kapatoes J, Ruchala K, Lu W, Wu C, Olivera G, et al. Image guidance for precise conformal radiotherapy. Int J Radiat Oncol Biol Phys 2003;56(1):89-105

[20]Ding GX, Munro P, Pawlowski J, Malcolm A, Coffey CW. Reducing radiation exposure to patients from 
kV-CBCT imaging. Radiother Oncol 2010;97(3):585-92.

[21] Ding GX, Munro P. Radiation exposure to patients from image guidance procedures and techniques to reduce the imaging dose. Radiother Oncol 2013;108(1):91-8.

[22] Morin O, Gillis A, Descovich M, Chen J, Aubin M, Aubry JF, et al. Patient dose considerations for routine megavoltage cone-beam CT imaging. Med Phys 2007;34(5):1819-27.

[23] Adamczyk M. Aspekty fizyczne leczenia stereotaktycznego w świetle doniesień zaprezentowanych podczas konferencji ASTRO 56 w San Francisco. Zeszyty Naukowe WCO, Letters in Oncology Science 2015;12(1):14-8

[24] Litoborska J. Najnowsze technologie wykorzystywane w procesie teleradioterapii w świetle doniesień konferencyjnych ASTRO 56. Zeszyty Naukowe WCO, Letters in Oncology Science 2015;12(3):33-6. 